\title{
Hubungan antara Indeks Massa Tubuh dengan Kadar Nitrit Oksid pada Masyarakat Etnik Minangkabau di Kota Padang
}

\author{
Nidia Purwadianti ${ }^{1}$, Fadil Oenzil ${ }^{2}$, Delmi Sulastri ${ }^{3}$
}

\begin{abstract}
Abstrak
Obesitas merupakan masalah kesehatan yang kompleks dengan penyebab multifaktorial. Obesitas berkaitan erat dengan peningkatan risiko sejumlah komplikasi seperti hipertensi. Salah satu mekanisme yang menghubungkan obesitas dengan hipertensi adalah disfungsi endotel sebagai akibat penurunan kadar nitrit oksid (NO). Pengukuran Indeks Massa Tubuh (IMT) merupakan salah satu indikator untuk menentukan obesitas. .Tujuan penelitian ini ialah menentukan hubungan IMT dengan kadar nitrit oksid pada masyarakat etnik Minangkabau. Desain penelitian adalah studi potong lintang dengan populasi masyarakat etnik Minangkabau usia 30 - 65 tahun di 4 kecamatan terpilih di Kota Padang. Jumlah subjek sebanyak 130 orang. Data responden merupakan data sekunder yang dianalisis menggunakan uji korelasi Pearson dan uji beda rerata dengan metode independent sample t-test. Hasil penelitian pada kelompok obesitas diperoleh $p$-value $=0,982$ dengan $r=-0,003$. Pada kelompok tidak obesitas didapatkan $p$ value $=0,924$ dan $r=-0,013$. Berdasarkan hasil tersebut dapat disimpulkan bahwa tidak terdapat hubungan yang

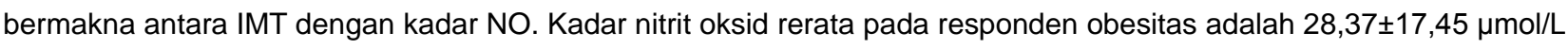
dan tidak obesitas adalah $23,91 \pm 11,55 \mu \mathrm{mol} / \mathrm{L}$ dengan $p$-value=0,084. Terdapat perbedaan rerata kadar NO kelompok obesitas dan tidak obesitas pada masyarakat etnik Minangkabau di Kota Padang namun tidak bermakna secara statistik. Diharapkan penelitian lebih lanjut dengan mempertimbangkan faktor lain yang mempengaruhi kadar NO selain IMT.
\end{abstract}

Kata kunci: indeks massa tubuh, kadar nitrit oksid, obesitas

\section{Abstract}

Obesity is a complex health problem with multifactorial causes. Obesity is strongly related to risk increase of many complications such as hypertension. One of the mechanisms that links obesity and hypertension is endhotelial disfunction due to nitric oxide (NO) level decrease. Body Mass Index (BMI) measurement is one of the indicators to determine obesity. The objective of this study was to determine correlation between BMI and NO level in Minangkabau ethnic group. The research design was cross sectional study, the population was Minangkabau ethnic group in the age group of 30-65 years old from 4 selected districts in Padang. The total subjects were 130. The secondary data were analyzed by using Pearson correlation and mean difference test by using independent sample test method. The results obtained in obese groupare $p$-value=0.982 and $r=-0.003$. In non-obese group $p$-value $=0.924$ and $r=-$ 0.013. Those findings suggest that there is no significant correlation between BMI and NO level. Mean NO level of obese group was $28.37 \pm 17.45 \mu \mathrm{mol} / \mathrm{L}$ and $23.91 \pm 11.55 \mu \mathrm{mol} / \mathrm{L}$ for non-obese group, $p$-value $=0.084$. It indicates that there is no significant correlation between obesity and NO level on Minangkabau ethnic group in Padang. It is suggested that other researchers conduct further research by considering other factors influencing NO level besides $B M I$.

Keywords: body mass index, nitric oxide, obesity

Affiliasi penulis : 1.Pendidikan Dokter FK UNAND (Fakultas Kedokteran Universitas Andalas Padang), 2. Bagian Biokima FK UNAND, 3. Bagian IImu Gizi FK UNAND
Korespondensi : Nidia Purwadianti, E-mail:

nidiapurwadianti@hotmail.com, Telp: (0751) 79502077 


\section{PENDAHULUAN}

Obesitas merupakan masalah kesehatan yang kompleks dengan penyebab multifaktorial antara lain hasil interaksi faktor genetik, lingkungan, metabolik, faal tubuh, pola hidup, sosial dan etnis. Prevalensi obesitas pada orang dewasa terus meningkat dalam satu dekade terakhir. Obesitas terutama berdampak pada tekanan darah, fungsi metabolisme, fungsi pernapasan, psikologis, adaptasi sosial, penyakit kardiovaskular dan diabetes mellitus. World Health Organization (WHO) pada tahun 2003 mencatat bahwa sekitar 1 milyar penduduk dunia mengalami berat badan lebih (overweight) dan sedikitnya 300 juta menderita obesitas secara klinis. WHO memprediksi bahwa 2,3 milyar orang dewasa akan mengalami berat badan lebih dan 700 juta orang mengalami obesitas di tahun 2015..$^{1-3}$

Prevalensi obesitas di negara maju meningkat seiring dengan perubahan diet, gaya hidup dan aktivitas fisik dalam kaitannya dengan perkembangan ekonomi dan urbanisasi. Pada tahun 2003 - 2004 di Amerika Serikat sebanyak $28,5 \%$ dewasa yang berumur 20-39 tahun, 36,8\% dewasa berumur $40-59$ tahun dan $31,0 \%$ dewasa berumur lebih dari 60 tahun termasuk ke dalam kategori obesitas. Obesitas memegang peranan penting sebagai penyebab 400.000 kematian di Amerika pada tahun 2000, peningkatan sebesar 33\% dari tahun 1990. . $^{1,4}$

Obesitas di beberapa negara berkembang juga telah menjadi masalah kesehatan yang serius. Berdasarkan data Riset Kesehatan Dasar (Riskesdas) pada tahun 2007, prevalensi obesitas umum di Indonesia yang diukur berdasarkan perhitungan Indeks Massa Tubuh (IMT) adalah 19,1\% (8,8\% berat badan lebih dan 10,3\% obesitas). Di tahun 2010, prevalensi nasional obesitas penduduk Indonesia mengalami peningkatan menjadi 11,7\%. Hasil pemantauan kesehatan dan status gizi orang dewasa di Sumatera Barat (Sumbar) oleh Dinas Kesehatan tahun 2004 diperoleh 33,5\% wanita dan 14,9\% pria terkena obesitas. Data ini menunjukkan bahwa masalah gizi lebih di Sumbar cukup tinggi dan memerlukan penanganan serius. ${ }^{6}$

Meningkatnya jumlah individu dengan obesitas disebabkan oleh perubahan pola makan dan aktivitas fisik. Pola makan yang tinggi karbohidrat, tinggi serat, dan rendah lemak berubah ke pola makan baru yang rendah karbohidrat, rendah serat, dan tinggi lemak. Membaiknya status ekonomi, kemudahan dan keterjangkauan harga menyebabkan terjadinya konsumsi makanan tinggi lemak secara berlebihan. ${ }^{7}$

Obesitas berkaitan erat dengan keadaan hipertensi. Obesitas meningkatkan risiko hipertensi sebesar 2,6 kali pada laki-laki dan 2,2 kali pada perempuan. Hal ini sejalan dengan penelitian Inou et al yang menyatakan bahwa risiko hipertensi meningkat dua kali lipat pada subjek dengan IMT $\geq 25 \mathrm{~kg} / \mathrm{m}^{2}$ dibandingkan subjek dengan IMT $22 \mathrm{~kg} / \mathrm{m}^{2}$. Salah satu mekanisme yang menghubungkan obesitas dengan hipertensi adalah disfungsi endotel sebagai akibat penurunan kadar nitrit oksid. ${ }^{8}$

Nitrit Oksid (NO) merupakan gas alamiah di dalam tubuh yang dilepaskan oleh sel endotel pembuluh darah dan berperan sebagai substansi dilator umur pendek. NO berperan penting pada pengaturan homeostasis vaskular sehingga gangguan pada sintesis NO berkaitan dengan peningkatan risiko penyakit kardiovaskuler. Pada individu dengan obesitas terjadi penurunan bioavailabilitas NO di sirkulasi yang disebabkan oleh gangguan sintesis NO dan atau peningkatan produksi Reactive Oxygen Species (ROS). Hal ini berkaitan dengan faktor metabolik seperti resistensi leptin dan resistensi insulin. Pada obesitas juga cendrung terjadi suatu keadaan yang disebut stres oksidatif yang menginduksi inaktivasi NO.-13

Gruber dkk melakukan penelitian tentang hubungan NO dengan berat badan remaja dan hasilnya menunjukkan bahwa pada remaja yang obesitas terjadi gangguan NO pathway yang mengakibatkan penurunan NO dan berkorelasi negatif dengan berat badan. ${ }^{14}$

\section{METODE}

Penelitian dilakukan di Fakultas Kedokteran Universitas Andalas pada bulan April - Mei 2013. Desain penelitian adalah studi potong lintang. Subjek berjumlah 130 orang yang berasal dari populasi masyarakat etnik Minangkabau usia 30 - 65 tahun di empat kecamatan terpilih di Kota Padang. Data responden merupakan data sekunder yang dianalisis menggunakan uji statistik korelasi Pearson dan 
independent samples t-test dengan derajat kemaknaan 0,05.

\section{HASIL}

Tabel 1. Distribusi responden berdasarkan umur, jenis kelamin, status perkawinan dan tingkat pendidikan

\begin{tabular}{lcc}
\hline \multicolumn{1}{c}{ Karakteristik } & $\mathbf{f}$ & $\%$ \\
\hline Umur & 10 & 7,7 \\
$30-39$ tahun & 120 & 92,3 \\
$40-65$ tahun & 130 & 100 \\
\hline Jumlah & & \\
\hline Jeniskelamin & 28 & 21,5 \\
Laki-laki & 102 & 78,5 \\
Perempuan & 130 & 100 \\
\hline Jumlah & & \\
\hline Status perkawinan & 2 & 1,5 \\
Belumkawin & 112 & 86,2 \\
Kawin & 16 & 12,3 \\
Janda/duda & 130 & 100 \\
\hline Jumlah & 29 & 22,3 \\
\hline Tingkat pendidikan & 29 & 22,3 \\
Tidaksekolah/tidaktamat SD & 22 & 16,9 \\
Tamat SD & 40 & 30,8 \\
Tamat SMP & 10 & 7,7 \\
Tamat SMA & 130 & 100 \\
Tamatakademi/PT & & \\
\hline Jumlah & & \\
\hline
\end{tabular}

Tabel 1 menunjukkan distribusi subjek berdasarkan umur, jenis kelamin, status perkawinan dan tingkat pendidikan. Sebagian besar responden berumur 40 - 65 tahun yaitu sebanyak 120 orang $(92,3 \%)$. Berdasarkan jenis kelamin, responden perempuan lebih banyak dibanding laki-laki yaitu sebanyak 102 orang (78,5\%). Dilihat dari status perkawinan dan tingkat pendidikan, paling banyak adalah responden yang berstatus kawin sebanyak 112 orang $(86,2 \%)$ dan tingkat pendidikan tamat SMA sebanyak 40 orang $(30,8 \%)$.

Tabel 2. Gambaran kadar nitrit oksid kelompok obesitas dan tidak obesitas masyarakat etnik Minangkabau di kota Padang

\begin{tabular}{cccccc}
\hline IMT & F & Mean & SD & Min & Maks \\
\hline Obesitas & 71 & 28,37 & 17,45 & 6,00 & 67,50 \\
$\begin{array}{c}\text { Tidak } \\
\text { obesitas }\end{array}$ & 59 & 23,91 & 11,55 & 12,00 & 64,50 \\
\hline
\end{tabular}

Tabel 2 menunjukkan gambaran kadar nitrit oksid pada kelompok obesitas dan tidak obesitas. Rerata kadar NO pada kelompok obesitas adalah $28,37 \pm 17,45 \mu \mathrm{mol} / \mathrm{L}$ dan pada kelompok tidak obesitas adalah $23,91 \pm 11,55 \mu \mathrm{mol} / \mathrm{L}$.

Tabel 3. Hubungan IMT kelompok obesitas dan tidak obesitas dengan kadar NO pada masyarakat etnik Minangkabau di kota Padang

\begin{tabular}{ccccc}
\hline & Rerata & SD & p & r \\
\hline Obesitas & 28,37 & 17,45 & 0,982 & $-0,003$ \\
TidakObesitas & 23,91 & 11,55 & 0,924 & $-0,013$ \\
\hline
\end{tabular}

Tabel 3 menunjukkan hubungan IMT dengan kadar NO. Pada kelompok obesitas, uji analisis dengan korelasi Pearson didapatkan nilai $p=0,982$ yang berarti tidak ada hubungan bermakna antara IMT kelompok obesitas dengan kadar NO. Pada kelompok tidak obesitas, hasil uji analisis dengan korelasi Pearson adalah $p=0,924$ yang berarti tidak terdapat hubungan bermakna antara IMT kelompok normal dengan kadar NO. Koefisien korelasi Pearson pada kedua kelompok menunjukkan bahwa IMT berkorelasi negatif dengan kadar NO dalam hubungan yang sangat lemah.

Tabel 4. Perbedaan rerata kadar NO kelompok obesitas dan tidak obesitas pada masyarakat etnik Minangkabau di kota Padang

\begin{tabular}{ccccc}
\hline Kelompok & $\mathbf{f}$ & Mean & SD & p \\
\hline Obesitas & 71 & 28,37 & 17,45 & \\
TidakObesitas & 59 & 23,91 & 11,55 & 0.084
\end{tabular}

Tabel 4 menunjukkan perbedaan rerata kadar NO kelompok obesitas dan tidak obesitas. Pada uji analisis $t$-test didapatkan nilai 0,084 yang berarti tidak terdapat hubungan bermakna secara statistik.

\section{PEMBAHASAN}

Berdasarkan hasil penelitian didapatkan rerata kadar NO responden obesitas 28,37 $\pm 17,45 \mu \mathrm{mol} / \mathrm{L}$ dengan nilai kadar NO tertinggi mencapai 67,50 $\mu \mathrm{mol} / \mathrm{L}$ dan terendah $6,00 \mu \mathrm{mol} / \mathrm{L}$. Rerata kadar NO responden tidak obesitas adalah $23,91 \pm 11,55 \mu \mathrm{mol} / \mathrm{L}$ 
dengan kadar NO tertinggi 64,50 $\mu \mathrm{mol} / \mathrm{L}$ dan terendah $12,00 \mu \mathrm{mol} / \mathrm{L}$. Pada kelompok obesitas, hasil korelasi Pearson menunjukkan hubungan tak bermakna antara IMT dengan kadar NO ( $p=0,982)$ dengan $r=-0,003$. Pada kelompok tidak obesitas juga didapatkan hubungan tidak bermakna antara IMT dengan kadar NO dimana $p=0,924$ dan $r=-0,013$. Hasil ini sejalan dengan penelitian yang dilakukan oleh DeSouza et al yang menyatakan bahwa tidak terdapat gangguan basal release NO yang bermakna pada dewasa overweight dan obesitas dibandingkan dewasa dengan IMT normal $(p=0,36) .{ }^{15}$

Hasil penelitian ini berbeda dengan penelitian oleh Gruber et al yang menyatakan terdapat korelasi negatif yang signifikan antara indeks massa tubuh dengan NOx ( $p<0,0001, r=-0,346)$. Perbedaan ini dapat disebabkan oleh faktor genetik dan perbedaan usia dimana yang menjadi subjek penelitian Gruber et al adalah anak-anak obesitas dan normal di negara Austria. $^{14}$

Peningkatan produksi ROS, resistensi leptin dan insulin yang diakibatkan oleh akumulasi jaringan lemak pada individu dengan IMT kategori obesitas berpengaruh terhadap kadar NO. IMT berkorelasi kuat dengan kandungan lemak tubuh, namun tidak dapat menggambarkan massa lemak tubuh secara tepat sehingga IMT yang besar belum tentu diakibatkan oleh banyaknya lemak total. Selain IMT, kadar NO juga dipengaruhi oleh banyak faktor lainnya seperti proses penuaan, aktivitas fisik dan asupan sumber nitrat anorganik serta antioksidan. 8,10,16,17

Hasil uji analisis dengan independent sample T-test menunjukkan tidak ada hubungan yang bermakna antara beda rerata kadar NO pada individu obesitas dengan tidak obesitas dengan $p=0,084$. Berdasarkan hasil penelitian didapat-kan rata-rata kadar NO responden obesitas adalah $28,37 \pm 17,45$ $\mu \mathrm{mol} / \mathrm{L}$, sedangkan pada responden tidak obesitas rata-rata kadar $\mathrm{NO}$ adalah $23,91 \pm 11,55 \mu \mathrm{mol} / \mathrm{L}$. Hal ini menunjukkan rerata kadar NO responden dengan obesitas lebih tinggi dibandingkan dengan responden yang tidak obesitas. Hal ini sesuai dengan penelitian Choi et al yang menyatakan bahwa produksi NO meningkat pada individu dengan obesitas baik pada laki-laki maupun perempuan. Penelitian Beltowski juga menunjukkan produksi NO meningkat akibat peningkatan produksi leptin yang berbanding lurus dengan peningkatan jaringan adiposa. ${ }^{18,19}$

Hasil penelitian ini berbeda dengan penelitian yang dilakukan Gruber et al yang menemukan penurunan NOx secara signifikan pada anak yang obesitas. Higashi et al menyatakan bahwa peningkatan stress oksidatif pada individu obesitas akan mengakibatkan penurunan bioavailabilitas NO. ${ }^{14,20}$

Choi et al menyatakan bahwa jaringan adiposa subkutan merupakan sumber potensial produksi NO. Pada individu dengan obesitas terjadi peningkatan produksi NO dan peningkatan ini dimulai ketika IMT mencapai angka > $25 \mathrm{~kg} / \mathrm{m}^{2}$. Penelitian Choi dkk menunjukkan konsentrasi NOx serum pada subjek laki-laki dan perempuan dengan kelebihan berat badan lebih tinggi 4,1 - 4,2 kali lipat dibandingkan subjek yang tidak obesitas. ${ }^{18}$

\section{KESIMPULAN}

Rerata kadar NO pada masyarakat etnik Minangkabau di Kota Padang kelompok obesitas berada pada kisaran normal, rerata kadar NO pada kelompok tidak obesitas berada di bawah kisaran normal.

Tidak terdapat hubungan bermakna antara IMT dengan kadar NO pada masyarakat etnik Minangkabau di Kota Padang.

Terdapat perbedaan rerata kadar NO kelompok obesitas dan tidak obesitas pada masyarakat etnik Minangkabau di Kota Padang namun tidak bermakna secara statistik.

\section{UCAPAN TERIMA KASIH}

Ucapan terimakasih kepada Prof. dr. Fadil Oenzil, PhD, Sp.GK dan Prof. Dr. dr. Delmi Sulastri, MS., Sp.GK atas bimbingan, bantuan dan motivasi dalam penelitian ini.

\section{DAFTAR PUSTAKA}

1. Galuska DA, Khan LK. Obesity. A public health perspective. Dalam: Bowman BA, Russell RM, editor (penyunting). Present knowledge in Nutrition. Edisi ke-8. Washington DC: ILSI Press; 2001. hlm.531-6. 
2. Hariyanto D, Madiyono B, Sjarif DR, Sastroasmoro S. Hubungan ketebalan tunika intima media arteri carotis dengan obesitas pada remaja. Sari Pediatri; 2009.

3. WHO Expert Consultation. Appropriate bodymass index for asian populations and its implications for policy and intervention strategies. The Lancet. 2004; 363: 157-63.

4. Ogden CL, Carroll MD, Curtin LR, McDowell MA, Tabak CJ, Flegal KM. Prevalence of overweight and obesity in the United States 1999-2004. JAMA. 2006;295(13):1549-55.

5. Vander AJ, Luciano DS, Sherman JH. Human physiology: The mechanism of body function. Edisi ke-8. Singapore: McGraw-Hill Companies; 2001:728-90.

6. Departemen Kesehatan Republik Indonesia. Riset kesehatan dasar (Riskesdas) 2007. Jakarta: Depkes RI; 2008.

7. Almatsier, Sunita. Prinsip dasar ilmu gizi. Jakarta: PT. Gramedia Pustaka Utama; 2006.

8. Lilyasari O. Hipertensi dengan obesitas: adakah peran endotelin-1? J Kardiol Ind. 2007;28:460-75.

9. Dorland WAN. Kamus kedokteran Dorland. Edisi ke-29. Jakarta: EGC; 2002.

10. Sulastri D, Rahmatini, Lipoeto NI, Edwar Z. Pengaruh asupan antioksidan terhadap ekspresi gen eNOS3 pada penderita hipertensi etnik Minangkabau. Maj Kedokt Indon. 2010;60(12): 564-70.

11. Fenster CP, Darley-Usmar VM, Landar AL, Gower BA, Weinsier RL, Hunter GR, et al. Weight loss and race modulate nitric oxide metabolism in overweight women. Free Radical Biology \& Medicine. 2004; 37(5): 695-702.
12. Morrison R. The Zucker rat as a model of obesityhypertension (dissertation). USA: Marshall University; 2006.

13. Cahjono $\mathrm{H}$. Hubungan resistensi insulin dengan kadar nitric oxide pada obesitas abdominal. J Peny Dalam. 2007; 8(1): 23-36.

14. Gruber HJ, Mayer C, Mangge H, Fauler G, Grandits N, Wilders-Truschnig M. Obesity reduces the bioavailability of nitric oxide in juveniles. International Journal of Obesity. 2008; 32:826-31.

15. DeSouza CA, Guilder GP, Greiner JJ, Smith DT, Hoetzer GL, Stauffer BL. Basal endothelial nitric oxide release is preserved in overweight and obese adults. Obesity Research. 2005;13(8): 1303-6.

16. Mumpuni, Yekti, Wulandari A. Cara jitu mengatasi kegemukan. Yogyakarta: Andi Offset; 2010. hlm. 1-22.

17. Sutadarma IWG, Sayogo S, Effendi I. Pengaruh jus bayam terhadap kadar NOx serum dan tekanan darah pada laki-laki dewasa muda. Maj Kedokt Indon. 2010;60(4):163-71.

18. Choi JW, Pai SH, Kim SK, Ito M, Park CS, Cha YN. Increases in nitric oxide concentrations correlate strongly with body fat in obese humans. Clinical Chemistry. 2001;47(6):1106-9.

19. Beltowski J, Wójcicka G, Borkowska E. Human leptin stimulates systemic nitric oxide production in the rat. Obesity Research. 2002;10(9): 939-46.

20. Higashi $Y$, Sasaki S, Nakagawa K, Kimura M, Noma K, Sasaki S, et al. Low body mass index is a risk factor for impaired endothelium-dependent vasodilation in humans: Role of nitric oxide and oxidative stress. J Am Coll Cardiol. 2003;42(2): 256-63. 